\title{
Vertical migration behavior and horizontal distribution of brachyuran larvae in a low-inflow estuary: implications for bay-ocean exchange
}

\author{
Claudio DiBacco ${ }^{1, *}$, Don Sutton ${ }^{2}$, Laurie McConnico ${ }^{3}$ \\ ${ }^{1}$ Marine Life Research Group, Scripps Institution of Oceanography, La Jolla, California, 92093-0218, USA \\ ${ }^{2}$ San Diego Supercomputer Center, 9500 Gilman Drive, La Jolla, California 92093-0505, USA \\ ${ }^{3}$ Moss Landing Marine Laboratories, 8272 Moss Landing Road, Moss Landing, California 95039, USA
}

\begin{abstract}
Rhythmic vertical migration has been well documented as a behavioral mechanism of brachyuran larvae that are actively exported from or retained within estuaries with net tidal residual flows, such as partially mixed estuaries. However, the effectiveness of vertical migratory behavior in mediating net larval transport in a low-inflow estuary (LIE), which is characterized by little or no freshwater inflow for extended periods of time, has not been addressed. Larval transport hypotheses, developed using a validated hydrodynamic model of San Diego Bay (SDB; an LIE), predicted that vertical migratory behavior was necessary to transport larvae out of the bay, while larvae lacking vertical migratory behavior would be retained within the bay. These predictions were tested in a field study that examined the temporal and spatial (vertical and horizontal) distribution of 2 brachyuran families, Pachygrapsus crassipes (Grapsidae) and Lophopanopeus spp. (Panopeidae), sampled at 2 sites within SDB. P. crassipes zoeae exhibited vertical migratory behavior, which enhanced their net export from the bay. Stage I $P$. crassipes zoeae were concentrated in surface layers (0 to $2 \mathrm{~m}$ ) during nocturnal ebb tides, but exploited low-velocity conditions associated with the benthic-boundary layer, which retarded transport back into the bay during flood tide. The lack of Post-Stage I P. crassipes zoeae within SDB suggests that the observed vertical migratory behavior was an effective means for exiting the bay. Stage I and Post-Stage I Lophopanopeus spp. larvae were sampled within SDB, but exhibited no clear rhythmic migration patterns. The lack of vertical migratory behavior and the presence of all larval stages of development suggest that Lophopanopeus spp. larvae were retained within the bay throughout meroplanktonic development. Heterogeneous horizontal distributions of Stage I P. crassipes and Lophopanopeus spp. zoeae reflect hatching sites and physical circulation features which concentrate larvae at specific areas. Differences in larval behavior observed for grapsid and panopeid larvae in SDB had a significant effect on their dispersal and retention.
\end{abstract}

KEY WORDS: Larval behavior - Selective tidal stream transport - Low-inflow estuary - Vertical migration - Zoeae - Larvae - Numerical simulations - San Diego Bay · Pachygrapsus crassipes · Lophopanopeus spp.

Resale or republication not permitted without written consent of the publisher

\section{INTRODUCTION}

The majority of marine benthic invertebrates have 1 or more planktonic larval stages of development (mero-

\footnotetext{
*Present address: Biology Department, Woods Hole Oceanographic Institution, Woods Hole, Massachusetts 02543, USA. E-mail: cdibacco@whoi.edu
}

plankton) that may act as an agent for increased dispersal and gene flow between sessile or sedentary adult populations (McConaugha 1992, Levin \& Bridges 1995). Studies of meroplankton spawned within estuaries have revealed species that are retained throughout larval development until ready to settle and recruit to local adult populations (Cronin 1982). The larvae of other taxa are exported to open coastal waters, where 
they develop prior to reentering estuaries and recruiting to adult populations (Christy 1982). The coupling of vertical migration by larvae with differential horizontal advection associated with tidal phase, termed selective tidal stream transport, can mediate the horizontal distribution and dispersal of planktonic larvae (Epifanio 1988, McConaugha 1988). Bousfield (1955) recognized that vertical movements out of seaward-moving water layers could facilitate larval retention within an estuary. Vertical migratory behavior has been well documented in decapod larvae (recent studies include Paula 1989, Queiroga et al. 1994, 1997, Lochmann et al. 1995, Rodriguez et al. 1997, Garrison 1999). These studies have characterized the temporal and spatial (usually vertical) distribution of larvae to understand and predict transport within estuaries and between estuaries and the nearshore coastal environment.

The studies cited above were conducted in estuaries where freshwater input results in significant non-tidal residual flows and a net flux of water from the bay (partially mixed estuary) (Pritchard 1952, Dyer 1997). San Diego Bay (SDB) is representative of 'low-inflow estuaries' (LIE), where freshwater input is negligible or absent for extended periods of time (Largier et al. 1996, 1997). In these estuaries, buoyancy fluxes are dominated by air-water interactions, with a positive buoyancy flux due to heating and a negative buoyancy flux due to evaporation. The resultant buoyancy flux is often too weak to bring about vertical stratification, and instead of density-driven circulation the exchange of water with the nearshore coastal environment is tidally driven. This difference may influence the net transport of marine invertebrate larvae. For example, while uniformly distributed pelagic larvae will experience a net flux out of bays characterized by significant freshwater input due to non-tidal residual flows, the same larvae would experience significantly longer residence times within an LIE. We hypothesize that species that export their larvae into coastal waters during planktonic development will exploit tidally induced currents in LIE rather than rely on downstream residual flows that are weak or absent. Conversely, we hypothesize that species which retain their larvae within embayments may not require any vertical migratory behavior to achieve retention within LIE waters having long residence times (e.g., SDB). Differences in physical transport processes within partially mixed and low-inflow estuaries may influence the dispersal and exchange of planktonic larvae; however, such comparisons have never been made.

This study examines these larval transport hypotheses, developed using a hydrodynamic model of SDB, with field observations that characterize temporal and spatial (vertical and horizontal) distribution patterns of brachyuran larvae over tidal and diel cycles in SDB.
Field observations and model simulations are used to evaluate the influence of temporal changes in the vertical and horizontal distribution of larvae on their retention and dispersal within SDB and between the bay and coastal waters. This study represents one of a few that have sampled the sediment-water interface while considering the vertical distribution of meroplankton (see also Prytherch 1928, Carriker 1951). We have established the presence of zoeae on the bottom during critical phases of the tide, which has implications for larval behavior on net transport.

\section{MATERIALS AND METHODS}

Study area. This study was conducted in San Diego Bay $\left(32^{\circ} 40^{\prime} \mathrm{N}, 117^{\circ} 10^{\prime} \mathrm{W}\right.$; Fig. 1), a crescent-shaped embayment approximately $25 \mathrm{~km}$ long. The outer half of the bay averages 1 to $2 \mathrm{~km}$ in width, while the inner bay is 2 to $4 \mathrm{~km}$ wide. Bay and ocean waters are exchanged through a single channel, which averages 1 to $2 \mathrm{~km}$ in width and is 10 to $15 \mathrm{~m}$ deep. The inner portion of the bay is about $12 \mathrm{~m}$ deep in the dredged shipping channel and 1 to $4 \mathrm{~m}$ deep elsewhere. Tides in SDB are mixed diurnal/semidiurnal, with a dominant semidiurnal component (Peeling 1974). Spring high tides consistently occur early in the evening following dusk during late-spring and summer months, when this study was conducted. The tidal range from MHHW to

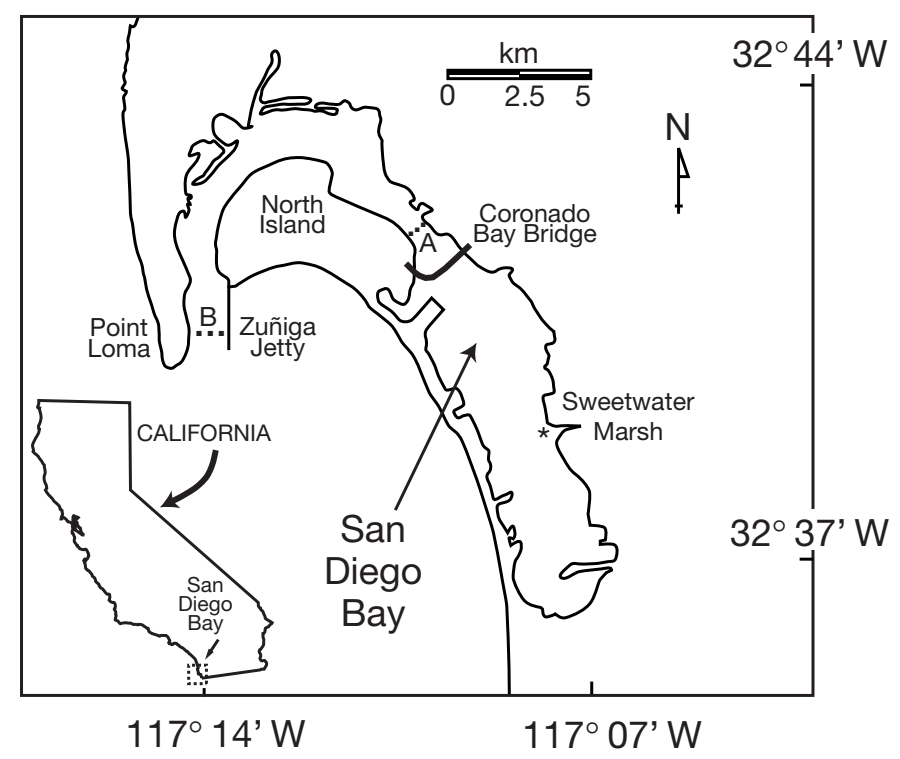

Fig. 1. Sampling locations within San Diego Bay. A: Coronado Bay Bridge transect; B: San Diego Bay Entrance transect; dots indicate positions of eastern, middle and western stations of each transect. Sweetwater Marsh served as the pointsource release site $(*)$ of simulated larvae for hydrodynamic model simulations 
MLLW is about $1.7 \mathrm{~m}$. Currents are strongest near the mouth, with maximum velocities between about 50 to $100 \mathrm{~cm} \mathrm{~s}^{-1}$ (Chadwick \& Largier 1999). Currents decrease toward the head of the bay due to a reduction in the upstream tidal prism. In south SDB, currents are usually less than $10 \mathrm{~cm} \mathrm{~s}^{-1}$.

$\mathrm{SDB}$, like other estuaries located in arid or Mediterranean climate regions of the world, experiences a dry season that typically extends from spring to autumn when freshwater inflow is negligible or absent. San Diego's climate is semi-arid, with an annual rainfall of about $25 \mathrm{~mm}$. Rainfall is associated with episodic storm events primarily during winter. Freshwater flows into the bay via several creeks; the most significant of these is the Sweetwater River (drainage area $540 \mathrm{~km}^{2}$; Conway \& Gilb 1989). Other sources of freshwater include non-point source runoff during winter storms and incidental runoff from agricultural and landscape watering. The negligible freshwater inflow results in sluggish circulation and a marked increase in average residence time estimates for the inner regions of SDB (Largier et al. 1996, 1997, Chadwick \& Largier 1999).

Larval transport simulations. The extent to which physical processes and larval behavior mediate the transport and dispersal of brachyuran larvae spawned in SDB was examined using computer simulations. A 2-dimensional (depth-averaged) hydrodynamic model (TRIM2D: tidal, residual, intertidal mudflat model), originally developed to describe tidal and residual circulation within San Francisco Bay (Cheng et al. 1993), was adapted to SDB to conduct transport and fate simulations of contaminants introduced to the bay via spills or storm-drain outfalls. We adapted TRIM2D to include simulated larvae with and without vertical migratory behavior for use as a predictive tool of larval transport. The model uses a finite-difference numerical scheme to solve 2-dimensional shallow water equations governing circulation and resolves circulation features to a horizontal resolution of $100 \mathrm{~m}$. Bottom depth values are derived from bathymetry data sets generated from a variety of depth sounding surveys. The water surface elevation along the open-ocean boundary in the model is driven by tidal forcing conditions corresponding to the dates of larval surveys (described below). The model calculates convective and diffusive transport components and has been calibrated and shown to be in good agreement with independently measured hydrodynamic variables using tide gauges, acoustic Doppler current profilers (ADCP), and mechanical current meter data (Wang et al. 1998). Since SDB receives little or no freshwater during most of the year, especially summer, buoyancy fluxes are dominated by air-water exchange. The resultant buoyancy flux from heating and evaporative processes in $\mathrm{SDB}$ is too weak to bring about vertical stratification and buoyancy-driven exchange (Largier et al. 1996). Therefore, SDB can be effectively represented using a 2-dimensional model.

A priori TRIM2D simulations were used to model bay-wide transport of (1) passive larvae with a uniform distribution in the water column and (2) active larvae with a rhythmic vertical migratory behavior that optimizes their chances for exchange out of SDB: larvae migrate into the upper $20 \%$ of the water column (top $2 \mathrm{~m}$ ) during ebb tide and onto the bottom during flood tide to minimize transport back into the bay. The vertical distribution of Stage I Pachygrapsus crassipes zoeae (see 'Results') suggested that zoeae may settle on the bottom during the flood tide to minimize transport into SDB. The efficiency of settling on the bottom versus aggregating in the bottom boundary layer $(2 \mathrm{~m}$ above the bottom) to maximize net transport from SDB was examined using TRIM2D simulations.

Vertical current profiles in SDB have been shown to be logarithmic, with flow velocity approaching zero at the sediment-water interface and a depth-averaged value occurring in the upper half of the water column. Horizontal larval transport velocities experienced by simulated larvae were determined from site-specific logarithmic velocity profiles and modeled larval depth distributions. During ebb tide, when migratory larvae were predicted to aggregate at the sediment-water interface, water velocity was set to zero. During flood tide, when larvae were concentrated in the upper $2 \mathrm{~m}$ of the water column, water-velocity estimates approached 1.2 times the depth-averaged velocity. TRIM2D simulations of non-migratory larvae employed tidal phasespecific, depth-averaged velocity estimates. The model simulation time-step was 6 min. Since Stage I Pachygrapsus crassipes zoeae observed in the laboratory swam at an approximate rate of $20 \mathrm{~mm} \mathrm{~s}^{-1}$ (DiBacco 1999), comparable with swimming rates reported by Chia et al. (1984), simulated larvae in shallow regions of the bay $(\leq 7 \mathrm{~m})$ were assumed capable of traversing the water column during a single 6 min time step. Zoeae in the deepest regions of the bay $(15 \mathrm{~m})$ were assumed to complete a vertical migration through the water column within two to three 6 min time steps.

Simulated larvae were released from the Sweetwater Marsh area (see Fig. 1), since this is the largest natural marsh in SDB with the largest expected point-source release of crab larvae in the bay. Also, Sweetwater Marsh is located in the inner half of SDB and provides a rigorous test for the efficiency of larval behavior as a mechanism to facilitate the export or retention of larvae. Simulated larvae were introduced during the nighttime flood to ebb tide transition during spring tidal conditions corresponding to larval survey dates (described below) and mimicking in situ larval release patterns observed for ovigerous Pachygrapsus crassipes. 
Study organisms. Temporal and spatial distributions of planktonic larvae of 2 brachyuran families were examined. In southern California, Pachygrapsus crassipes adults and larvae are widely distributed in low-energy bays and exposed coastal habitats; ovigerous females and newly hatched larvae are present from late spring to early fall (Ricketts et al. 1985, DiBacco 1999). P. crassipes zoeal stages are readily identifiable (Schlotterbeck 1976). Lophopanopeus spp. zoeae (L. bellus diegensis and L. frontalis) could not be distinguished from one another since zoeal stages of the latter species have not been described (Ricketts et al. 1985). These species co-occur as adults in the low intertidal zone of bays and estuaries from Monterey Bay to SDB and characteristically hatch larvae from late spring through summer (Knudsen 1958, 1959, Morris et al. 1980). The temporal and spatial distribution and abundance of larvae sampled in this study are presented for Stage I P. crassipes zoeae and for combined stages of Lophopanopeus spp. zoeae. Lophopanopeus spp. zoeal stages were combined since statistical results were consistent whether Stage I, Post-Stage I or combined larval stages of development were analyzed.

Sample collection. Field-sampled larvae were collected during 4 consecutive new and full moon spring tidal periods between 21 July 1997 and 2 September 1997 (Table 1). Two sampling field trips were conducted at the Coronado Bay Bridge (CBB) site and 2 at the San Diego Bay Entrance (SDBE) site (Fig. 1). Collection of plankton samples started in the late afternoon, during late-flood tide, and continued until high tide the following morning (Table 1). The nighttime tidal cycle was targeted because of sampling constraints (e.g., availability of equipment) and since preliminary field investigations indicated that Pachygrapsus crassipes zoeae were present in the water column mainly at night (DiBacco 1999).
Plankton samples were collected at the CBB transect, which consisted of 3 sampling stations located in the eastern, middle and western regions of the $500 \mathrm{~m}$ cross-channel transect (Fig. 1). Each station was sampled at 3 water depths: 0 to $2 \mathrm{~m}, 5$ to $7 \mathrm{~m}$, and $<2$ 'meters above the bottom' (mab), typically 8 to $11 \mathrm{~m}$ deep. The bottom samples included the sedimentwater interface during the September sampling period and from 0.5 to 2 mab during the July sampling dates. The CBB transect was sampled at 1 to $1.5 \mathrm{~h}$ intervals between (1) 18:00 h on 21 July and 11:00 h on 22 July and (2) 16:00 $\mathrm{h}$ on 1 September and $11: 00 \mathrm{~h}$ on 2 September.

Larval sample collections at the SDBE transect were conducted along a $1400 \mathrm{~m}$ cross-channel transect between Point Loma and Zuñiga Jetty (Fig. 1). Only the eastern station of the SDBE transect was sampled during the 4 to 5 August sampling period because of problems with sampling gear. Eastern, middle, and western regions were sampled on 18 to 19 August. Three depths were sampled at each station; 0 to $2 \mathrm{~m}$, 5 to $7 \mathrm{~m}$, and $<2 \mathrm{mab}$, including the sediment-water interface, typically 9 to $12 \mathrm{~m}$ deep.

Plankton samples were collected from a $7 \mathrm{~m}$ motorboat using a stainless steel pump ( 0.5 horsepower, $115 \mathrm{~V}$ motor) powered by a portable electric generator (1850 W). The pump was fitted with a 2 inch $(\sim 5.1 \mathrm{~cm})$ diameter hose and a vortex impeller that minimized damage to larvae. The pump's outflow was measured for each sampling depth (ca $0.3 \mathrm{~m}^{3} \mathrm{~min}^{-1}$ ) and used to standardize plankton abundance per unit volume of water sampled. Individual pump samples was typically 5 min in duration and corresponded to an approximate volume of $1.5 \mathrm{~m}^{3}$. Therefore, larval abundance estimates presented in this paper (see 'Results') have been standardized to a pumped water volume of $1.5 \mathrm{~m}^{3}$. This provides an accurate representation of the actual

Table 1. Sampling dates and corresponding lunar phase, sampling location $(\mathrm{CBB}=$ Coronado Bay Bridge transect; $\mathrm{SDBE}=\mathrm{San}$ Diego Bay Entrance transect), stations sampled, station depth, tidal regime, and total number (n) of Stage I Pachygrapsus crassipes zoeae and combined Stage I and Post-Stage I zoeae of Lophopanopeus spp. larvae (L. bellus diagenisis and L. frontalis) sampled

\begin{tabular}{|c|c|c|c|c|c|c|c|c|}
\hline $\begin{array}{l}\text { Sampling } \\
\text { date }\end{array}$ & $\begin{array}{l}\text { Lunar } \\
\text { phase }\end{array}$ & $\begin{array}{l}\text { Sampling } \\
\text { location }\end{array}$ & $\begin{array}{l}\text { Stations } \\
\text { sampled }\end{array}$ & $\begin{array}{c}\text { Station } \\
\text { depth }(\mathrm{m})\end{array}$ & $\begin{array}{l}\text { High } \\
\text { tide }\end{array}$ & $\begin{array}{l}\text { Low } \\
\text { tide }\end{array}$ & $\begin{array}{c}\text { Pachygrapsus } \\
\text { crassipes (n) }\end{array}$ & $\begin{array}{l}\text { Lophopanopeus } \\
\text { spp. (n) }\end{array}$ \\
\hline $\begin{array}{l}\text { 21-22 Jul } 1997 \\
(18: 00-11: 00 \mathrm{~h})\end{array}$ & Full & CBB & $\begin{array}{l}\text { East-channel } \\
\text { Mid-channel } \\
\text { West-channel }\end{array}$ & $10-12$ & $\begin{array}{c}22: 59 \mathrm{~h} \\
(2.13 \mathrm{~m})\end{array}$ & $\begin{array}{c}5: 50 \mathrm{~h} \\
(-0.13 \mathrm{~m})\end{array}$ & 198 & 1768 \\
\hline $\begin{array}{l}\text { 4-5 Aug } 1997 \\
(18: 00-11: 30 \mathrm{~h})\end{array}$ & New & SDBE & East-channel & $7-12$ & $\begin{array}{l}22: 27 \mathrm{~h} \\
(1.71 \mathrm{~m})\end{array}$ & $\begin{array}{c}5: 20 \mathrm{~h} \\
(-0.01 \mathrm{~m})\end{array}$ & 348 & 29 \\
\hline $\begin{array}{l}\text { 18-19 Aug } 1997 \\
(17: 00-11: 00 \mathrm{~h})\end{array}$ & Full & SDBE & $\begin{array}{l}\text { East-channel } \\
\text { Mid-channel } \\
\text { West-channel }\end{array}$ & $7-12$ & $\begin{array}{l}22: 07 \mathrm{~h} \\
(2.27 \mathrm{~m})\end{array}$ & $\begin{array}{c}4: 52 \mathrm{~h} \\
(-0.31 \mathrm{~m})\end{array}$ & 847 & 60 \\
\hline $\begin{array}{l}\text { 1-2 Sep 1997 } \\
(16: 00-11: 00 \mathrm{~h})\end{array}$ & New & CBB & $\begin{array}{l}\text { East-channel } \\
\text { Mid-channel } \\
\text { West-channel }\end{array}$ & $10-12$ & $\begin{array}{l}21: 53 \mathrm{~h} \\
(1.91 \mathrm{~m})\end{array}$ & $\begin{array}{c}4: 28 \mathrm{~h} \\
(-0.04 \mathrm{~m})\end{array}$ & 371 & 1903 \\
\hline
\end{tabular}


number of larvae sampled per station. Seawater was sieved through a $300 \mu \mathrm{m}$ Nitex plankton net that was partially submerged to prevent damage to organisms. The net was washed down with seawater to concentrate samples in $500 \mathrm{ml}$ bottles. Samples were stored on ice until they could be transported to the laboratory, where they were held at $5^{\circ} \mathrm{C}$. If samples were not sorted within $24 \mathrm{~h}$, zooplankton was concentrated onto Nitex filters, placed into $50 \mathrm{ml}$ disposable centrifuge tubes, frozen in liquid nitrogen, and thawed just prior to sorting. Crab zoeae were sorted and identified to the lowest possible taxa with the aid of a dissecting microscope.

Statistical analysis. Analysis of variance (ANOVA) and a posteriori Student's $t$-tests were used to test the effects of tidal and diel phase on the spatial distribution and abundance of sampled brachyuran larvae. Larval concentration data (no. $1.5 \mathrm{~m}^{-3}$ ) were $\log (x+1)$ transformed and percent data were arcsine-transformed when data did not meet assumptions of normality (Kolmogorov-Smirnoff) and homogeneity of variance (Bartlett's test or Scheffés test). Student's $t$ alpha levels were Bonferroni-adjusted to reduce the likelihood of Type I errors (Sokal \& Rohlf 1995).

The eastern, middle and western regions of each transect sampled served as replicates for each depth sampled, with the exception of the 4 to 5 August sampling period, when only the eastern portion of the channel was sampled. Before pooling data across horizontal stations, larval concentration estimates were tested (ANOVA) for differences in the cross-channel concentration of larvae. Only stations not differing statistically in larval concentration estimates were combined.

Tidal and diel light cycles were in phase during the spring-tide sampling periods targeted in this study; ebb tides always coincided with nocturnal sampling. Diurnal ebbing tides were never sampled, while flood tides were sampled during nocturnal and diurnal sampling. Thus the different effects of tidal phase and diel phase on the vertical distribution of brachyuran larvae could not be separated and assessed statistically. Since tidal and diel phases were confounded, 2-way ANOVAs were performed to test for effects of tidal or diel phase and sampling depth on the concentration of Pachygrapsus crassipes or Lophopanopeus spp. larvae.

\section{RESULTS}

\section{Larval transport simulations}

Snapshots of SDB-wide larval transport during TRIM2D model simulations are shown in Fig. 2. Model simulations predicted that larvae with rhythmic vertical migratory behavior (within $2 \mathrm{~m}$ of the surface during ebb tide; within $2 \mathrm{~m}$ above the bottom during flood tide) experienced net transport towards the bay's entrance (Fig. 2A-D). Simulations of passive larvae that were uniformly distributed in the water column predicted that larvae would be retained within the inner half of SDB (Fig. 2E-H). Both simulations indicated that larvae were maintained on the eastern side of the channel during the first ebb tide after release. This distribution persisted through subsequent ebb tides for simulated larvae with vertical migratory behavior.

Time-series plots of the relative distribution of simulated larvae released from Sweetwater Marsh indicate that vertically migrating larvae are initially transported from inner to outer regions of SDB and into coastal waters in a matter of 30 to $40 \mathrm{~h}$ (Fig. 3A). Simulated larvae that did not exhibit vertical migratory behavior were retained within SDB, with less than $10 \%$ dispersing into coastal waters after $70 \mathrm{~h}$ (Fig. 3B).

Simulated larvae that migrated onto the bottom during flood tides were transported from SDB more quickly than larvae that migrated only into the bottom boundary layer (within $2 \mathrm{~m}$ above the bottom) (Fig. 4). Time-series plots of the percentage of simulated larvae transported into nearshore coastal waters after $70 \mathrm{~h}$ showed that approximately twice the number of larvae reached coastal waters if the larvae exploited the sediment-water interface during flood tidal conditions $(81 \%)$ versus migrating within $2 \mathrm{~m}$ of the bottom $(41 \%)$.

\section{Species composition and abundance}

More than $99 \%$ of Pachygrapsus crassipes larvae sampled in this study were newly hatched Stage I zoeae. Panopeid larvae consisted of Lophopanopeus bellus diagenesis and L. frontalis, identified to genera from published descriptions of zoeal development (Knudsen 1958, 1959, Rice 1980, Ingle 1992). The majority of Lophopanopeus spp. zoeae sampled (ca 97\%) were collected from the CBB site, with about $58 \%$ of these larvae in the first zoeal stage of development. There were no significant differences in the concentration of $P$. crassipes zoeae sampled during $\mathrm{CBB}$ and SDBE sampling dates (ANOVA, $F_{3,296}=1.988, \mathrm{p}=0.116$ ) (Figs $5 \&$ 6) or Lophopanopeus spp. zoeae sampled during CBB sampling dates $\left(F_{1,169}=0.258, \mathrm{p}=0.613\right)$ (Fig. 7), therefore species-specific density estimates could be combined across sampling periods for subsequent statistical analyses. 

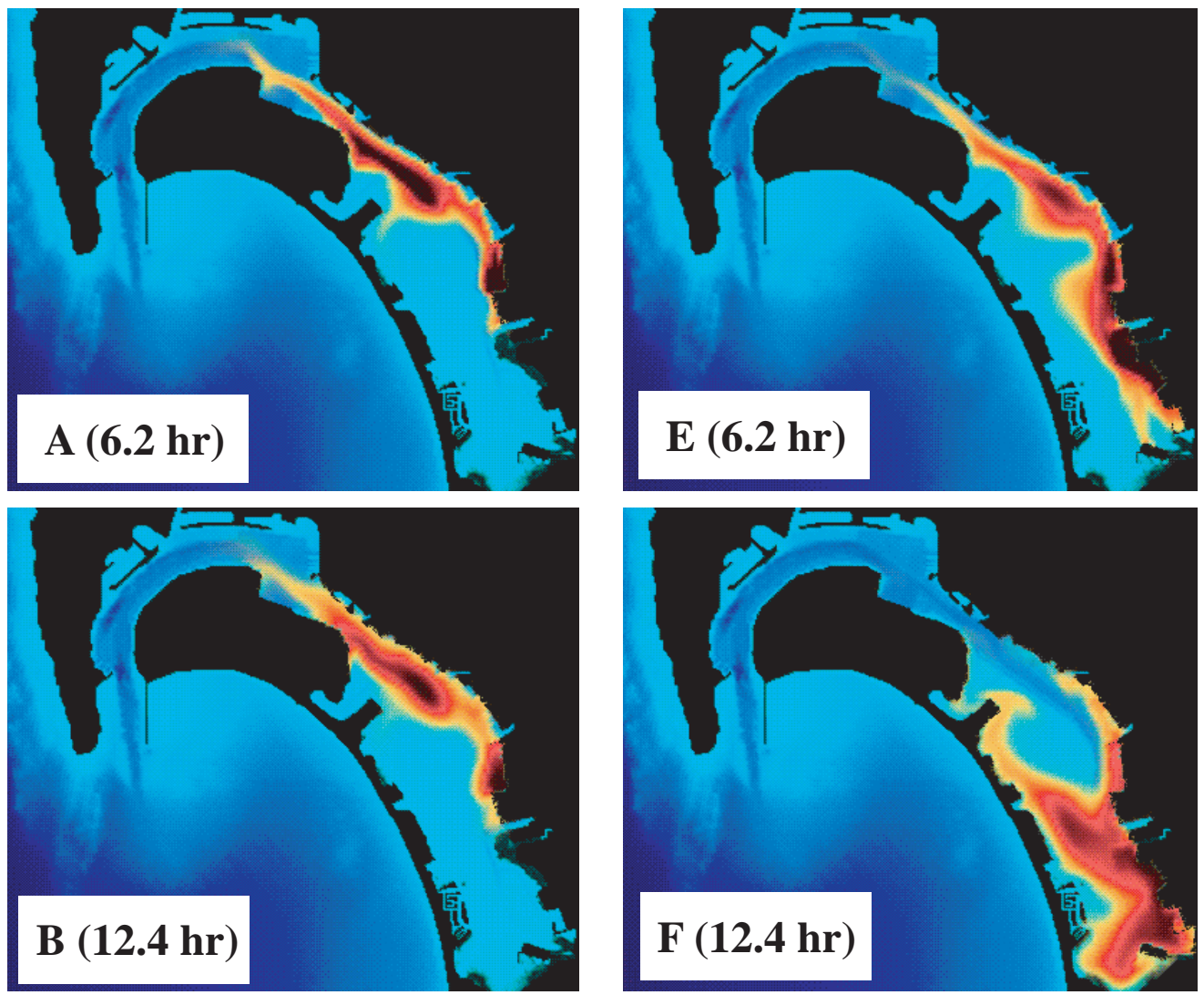

Fig. 2. Tidal residual intertidal mudflat model (TRIM2D) simulations for brachyuran larvae released from identified intertidal and high intertidal habitats off Sweetwater Marsh on the eastern side of
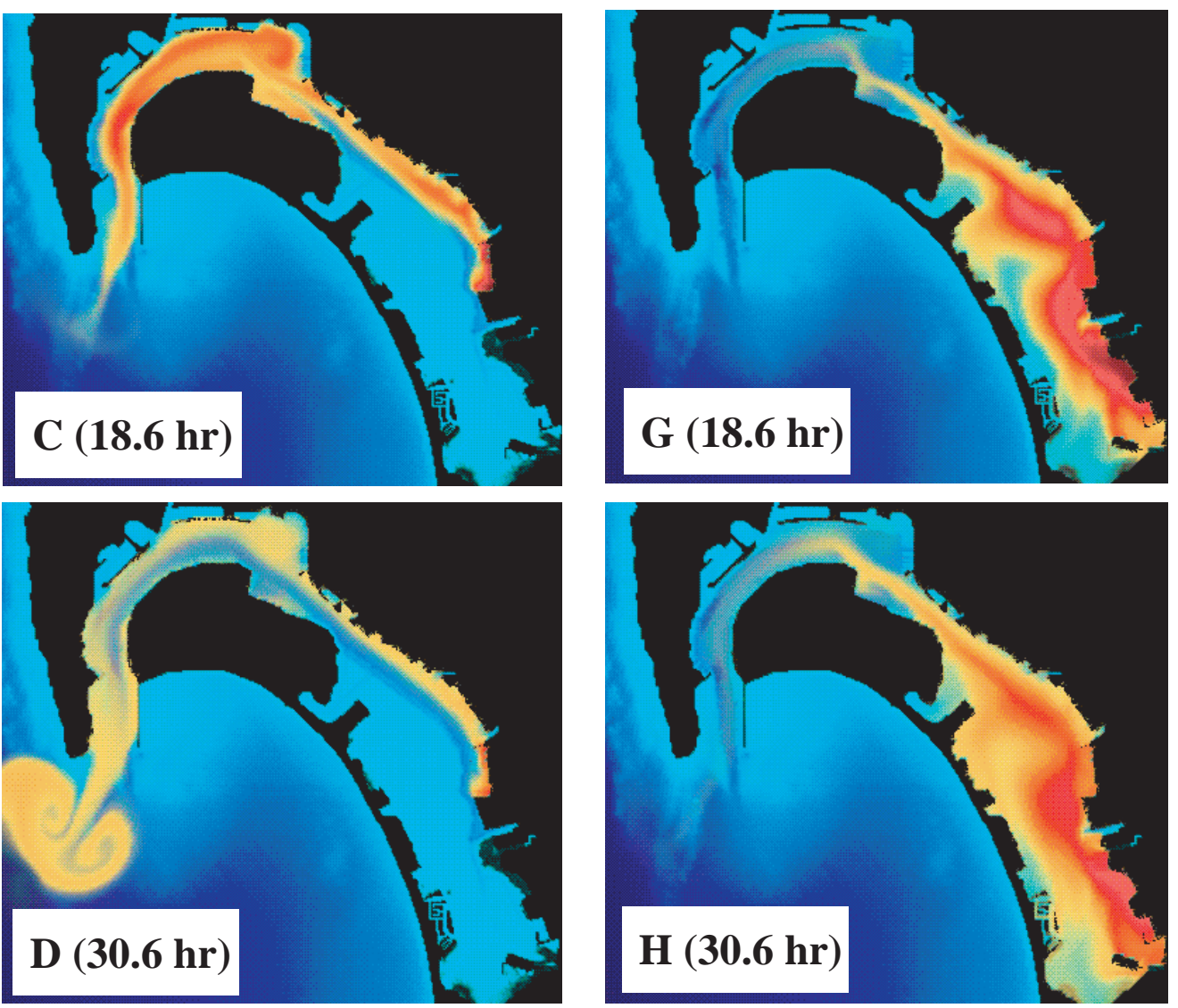

San Diego Bay (see Fig. 1 for location of larval release site). Simulated larvae with vertical migratory behavior (A-D) are aggregated in surface layers (within surface $2 \mathrm{~m}$ ) during flood-tide phases and in benthic layers during ebb tidal phases (within $1 \mathrm{~m}$ of bottom). Migratory larvae are concentrated in the eastern half of the channel at the Coronado Bay Bridge site and experience a net transport towards the San Diego Bay entrance. Simulated larvae without vertical migratory behavior $(\mathrm{E}-\mathrm{G})$ produce larval distributions concentrated in the back of San Diego Bay. Relative larval abundance is represented by black, red, orange and yellow shading, with red and darker areas indicating higher concentrations, following the initial ebb tide $(6.2 \mathrm{~h}$ postrelease: $A$ and $E$ ), flood tide (12.4 h post-release: $B$ and F), ebb tide (18.6 $\mathrm{h}$ post-release: $\mathrm{C}$ and $\mathrm{G}$ ), and subsequent ebb tide (30.6 h post-release: $\mathrm{D}$ and $\mathrm{H}$ ) 


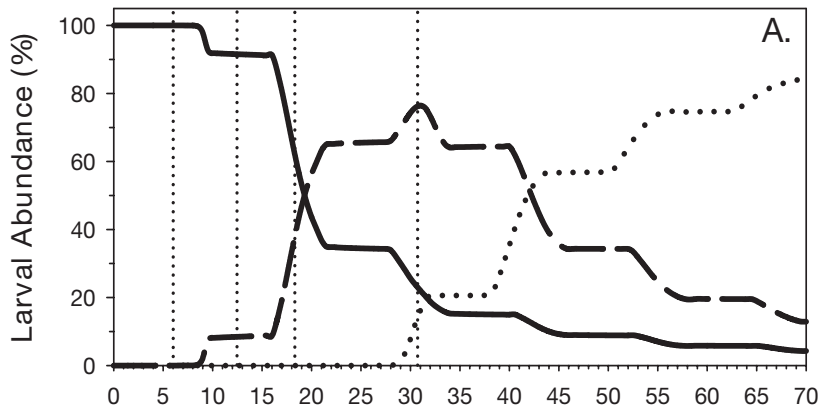

$$
\text { Inner SDB } \quad \text { O Outer SDB } \quad \cdots \text { Coastal }
$$

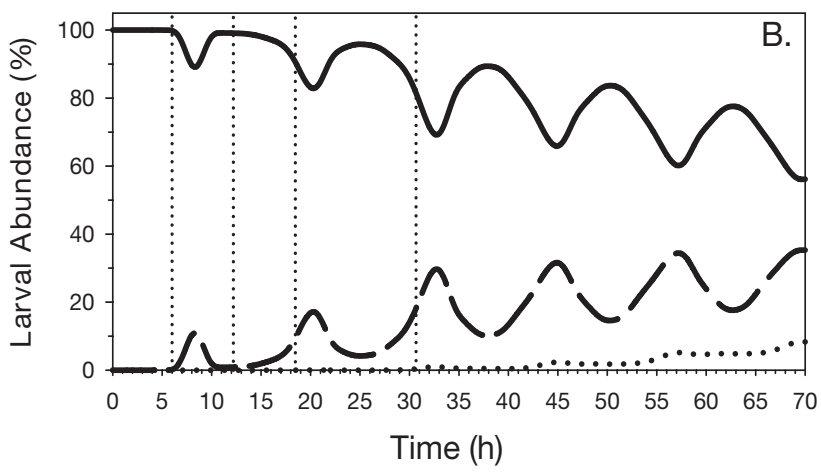

Fig. 3. Time-series plots quantifying relative horizontal distribution of simulated larvae released from Sweetwater Marsh, San Diego Bay (Fig. 2). Relative abundance (\%) estimates between inner and outer regions of San Diego Bay and nearshore coastal waters are for larvae (A) with and (B) without vertical migratory behavior. Vertical dotted lines correspond to TRIM2D simulation snapshots in Fig. 2 for 6.2, 12.4, 18.6 and $30.6 \mathrm{~h}$ post-release

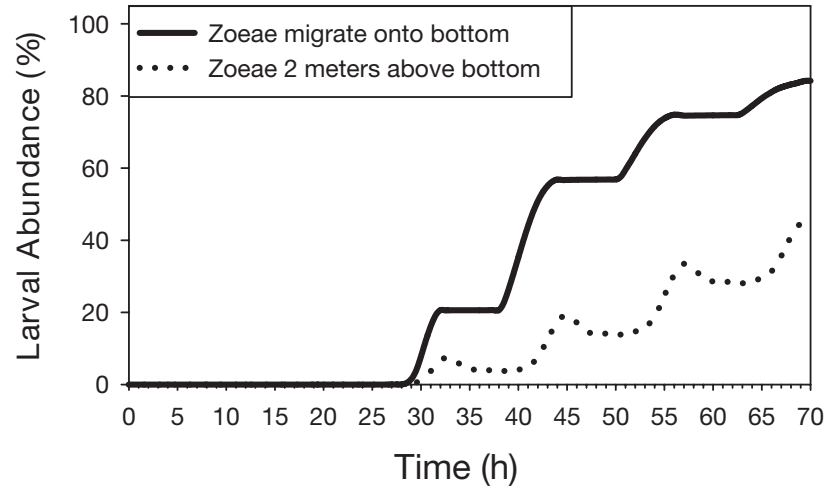

Fig. 4. Time-series plot showing relative abundance (\%) of simulated larvae transported from San Diego Bay into nearshore coastal waters. Continuous line: zoeae that maximize transport from San Diego Bay by settling on the bottom during the flood-tide phase; dotted line represents larvae that migrate within $2 \mathrm{~m}$ of bottom during the flood-tide phase, but do not settle on the bottom

migration of Stage I $P$. crassipes zoeae is suggested from mean larval concentration estimates collected during the nocturnal-ebb tide to diurnal-flood tide transition of the 4 to 5 August sampling period (see Transects 8 to 15: Fig. 6A). The relative concentration of $P$. crassipes zoeae is highest in the surface layer during late-ebb (Transects 7 to 9), followed by mid-depth during the ebb- to flood-tide transition (Transect 11) and in the bottom layer during flood tide (Transects 12 to 15: Fig. 6A).

\section{Vertical distribution of larvae}

\section{Pachygrapsus crassipes}

Larval vertical migratory behavior was observed in Stage I Pachygrapsus crassipes zoeae hatched in SDB. The concentration of Stage I $P$. crassipes larvae sampled in this study did not vary with tidal phase, diel phase or sampling depth when analyzed independently (Table 2). Significant interaction terms suggest a strong effect of tidal phase and diel phase on the vertical distribution of $P$. crassipes zoeae (Table 2). The highest densities of Stage I $P$. crassipes larvae consistently occurred in the surface sampling layer (0 to $2 \mathrm{~m}$ ) during nocturnal ebb-tide conditions (Table 3 ) and in the bottom layer (0 to 2 mab) during diurnal flood-tide conditions (Table 3, Figs $5 \&$ 6). A downward
Table 2. Pachygrapsus crassipes and Lophopanopeus spp. Two-way ANOVA comparing effects of tidal phase $(\mathrm{T})$ and sampling depth $(\mathrm{Z})$ or diel phase (D) and sampling depth on larval abundance (log $[x+1]$ transformed) of Stage I P. crassipes zoeae and Lophopanopeus spp. larvae (all stages combined). Results from the analyses of Stage I and Post-Stage I Lophopanopeus spp. zoeae are not presented separately since significance levels of terms were similar to those revealed by the analysis of combined stages of development. Results from a posteriori multiple comparisons are given in Table 3

\begin{tabular}{|lcccrrr|}
\hline \multirow{2}{*}{ Source } & \multicolumn{3}{c}{ Pachygrapsus crassipes } & \multicolumn{3}{c|}{ Lophopanopeus spp. } \\
& df & F-ratio & p-value & df & F-ratio & p-value \\
& & & & & & \\
Tidal phase (T) & 1 & 1.551 & 0.210 & 1 & 15.815 & $<0.001$ \\
Depth (Z) & 2 & 2.197 & 0.114 & 2 & 1.391 & 0.252 \\
T $\times$ Z & 2 & 22.299 & $<0.001$ & 2 & 2.477 & 0.087 \\
Error & 213 & & & 165 & & \\
& & & & & & \\
Diel phase (D) & 1 & 2.568 & 0.111 & 1 & 13.971 & $<0.001$ \\
Depth (Z) & 2 & 2.308 & 0.102 & 2 & 1.467 & 0.234 \\
D $\times$ Z & 2 & 25.143 & $<0.001$ & 2 & 2.142 & 0.121 \\
Error & 213 & & & 165 & & \\
& & & & & & \\
\end{tabular}




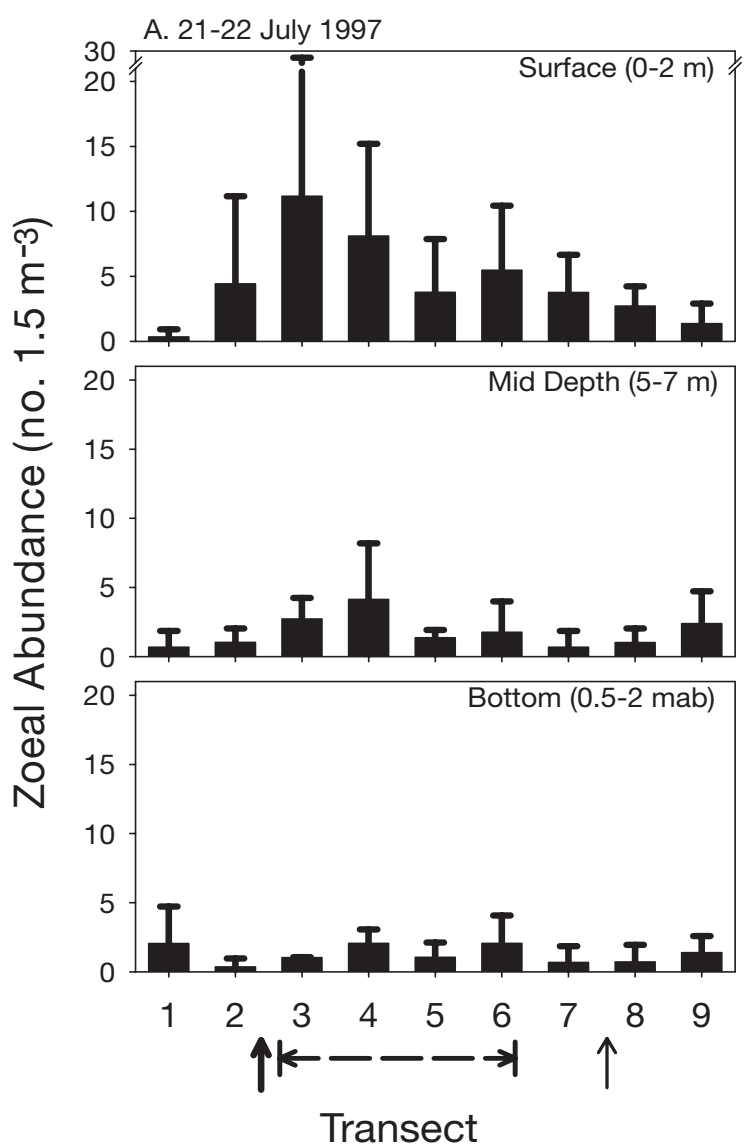

B. 1-2 September 1997

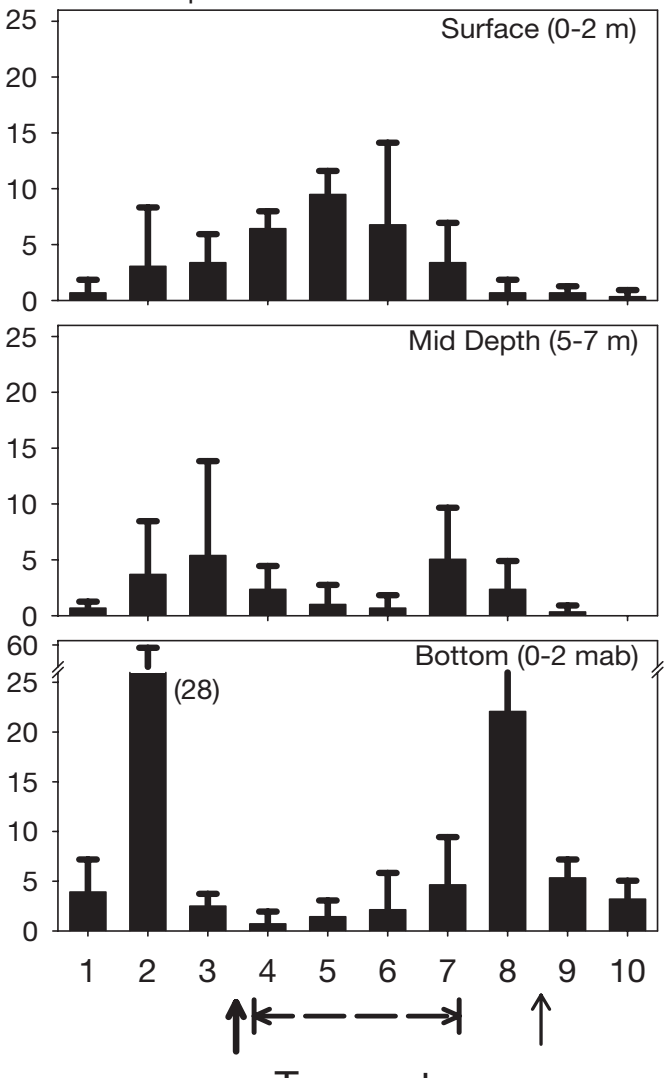

Fig. 5. Pachygrapsus crassipes. Temporal and vertical distribution of Stage I zoeae sampled at Coronado Bay Bridge transect on 21-22 July and 1-2 September 1997. Mean zoeal abundance was calculated by averaging depth-specific larval abundance estimates from eastern, middle and western stations for each transect, respectively. Dashed line along the $x$-axes: ebb-tide phase; thick and thin vertical arrows on $x$-axes: onset of sunset and sunrise, respectively; numbers in parentheses next to vertical bar in last graph indicates maximum value that exceeds range on y-axis. mab: meters above bottom. Error bars $=1 \mathrm{SD}$

Table 3. Pachygrapsus crassipes and Lophopanopeus spp. One-way ANOVA comparing larval abundance estimates (mean \pm SD) for surface ( $\mathrm{T}=0$ to $2 \mathrm{~m}$ ), mid-depth $(\mathrm{M}=5$ to $7 \mathrm{~m})$, and bottom ( $\mathrm{B}=<2 \mathrm{mab}$ : meters above the bottom) layers sampled during ebb and flood tides during July, August and September 1997 sampling periods. Stage I zoeae were analyzed for P. crassipes; Stage I and Post-Stage I Lophopanopeus spp. zoeae were combined for the analysis presented; separate analyses of Stage I and PostStage I Lophopanopeus spp. zoeae failed to identify any statistical differences. Statistically significant multiple comparison results (Bonferroni-corrected Student's $t$-test) are given for each ANOVA that identified significant differences. July 1997 sampling period was not analyzed for $P$. crassipes since the sediment-water interface was not adequately sampled during this period

\begin{tabular}{|c|c|c|c|c|c|c|c|c|}
\hline Sampling date & Tidal phase (T) & Surface & Mid-depth (M) & Bottom (B) & $\mathrm{n}$ & $F$-ratio & $\mathrm{p}$-value & Student's $t$ \\
\hline \multicolumn{9}{|l|}{ P. crassipes } \\
\hline \multirow{2}{*}{ 4-5 Aug } & Ebb & $4.06(3.61)$ & $1.91(2.79)$ & $1.07(1.27)$ & 12 & 4.367 & 0.038 & $\mathrm{~T}>\mathrm{M}, \mathrm{B}$ \\
\hline & Flood & $0.71(0.68)$ & $1.04(1.09)$ & $5.44(5.64)$ & 30 & 3.091 & 0.060 & - \\
\hline \multirow[t]{2}{*}{ 18-19 Aug } & Ebb & $29.88(31.3)$ & $13.28(16.9)$ & $2.31(3.74)$ & 33 & 4.010 & 0.028 & $\mathrm{~T}, \mathrm{M}>\mathrm{B}$ \\
\hline & Flood & 1.73 (1.63) & $2.39(2.58)$ & $23.63(39.46)$ & 30 & 7.453 & 0.002 & $\mathrm{~T}, \mathrm{M}<\mathrm{B}$ \\
\hline \multirow{2}{*}{ 1-2 Sep } & Ebb & $6.52(2.49)$ & $2.27(1.99)$ & $2.22(1.70)$ & 33 & 5.694 & 0.008 & $\mathrm{~T}>\mathrm{M}, \mathrm{B}$ \\
\hline & Flood & $1.47(1.37)$ & $2.07(2.14)$ & $10.91(11.3)$ & 51 & 12.787 & $<0.001$ & $\mathrm{~T}, \mathrm{M}<\mathrm{B}$ \\
\hline \multicolumn{9}{|c|}{ Lophopanopeus spp. } \\
\hline \multirow[t]{2}{*}{$21-22 \mathrm{Jul}$} & $\mathrm{Ebb}$ & 31.33 (8.09) & $21.10(11.3)$ & $33.04(13.9)$ & 33 & 1.207 & 0.312 & - \\
\hline & Flood & $18.06(19.5)$ & $18.48(6.66)$ & $16.07(9.45)$ & 42 & 0.978 & 0.384 & - \\
\hline \multirow[t]{2}{*}{ 1-2 Sep } & Ebb & 22.60 (10.4) & 22.70 (16.3) & $32.92(15.1)$ & 33 & 1.573 & 0.223 & - \\
\hline & Flood & 12.13 (1.81) & 21.97 (8.64) & 23.07 (9.28) & 51 & 0.759 & 0.473 & - \\
\hline
\end{tabular}




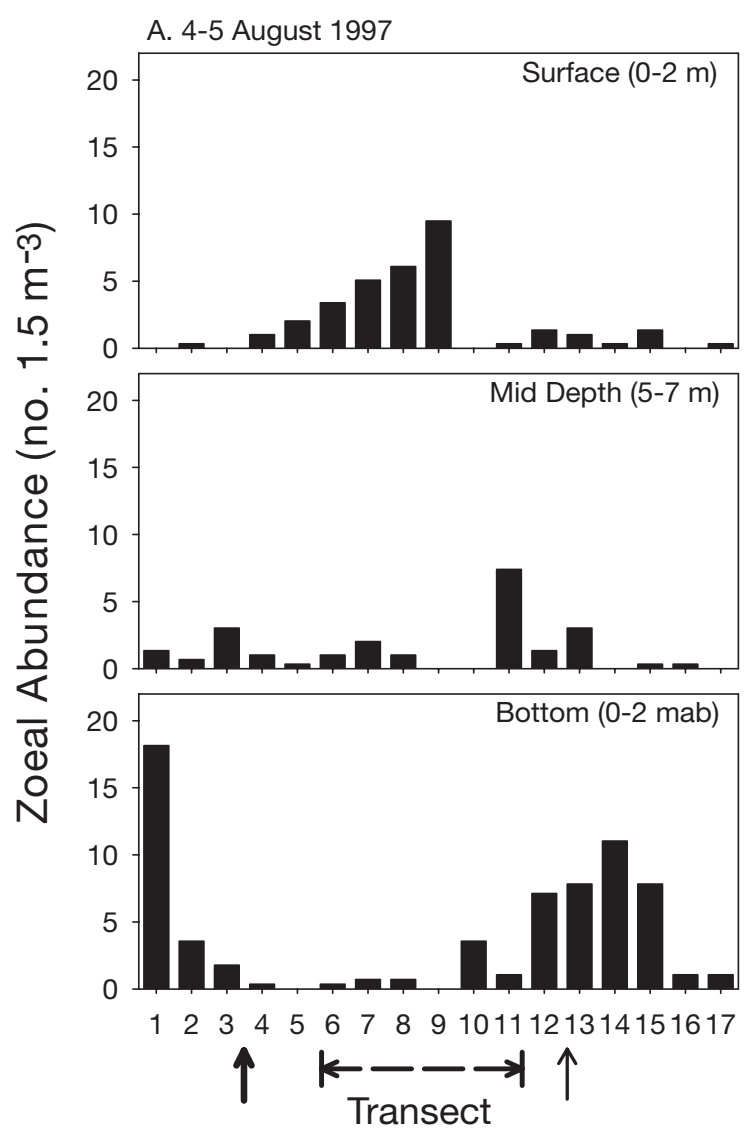

B. 18-19 August 1997
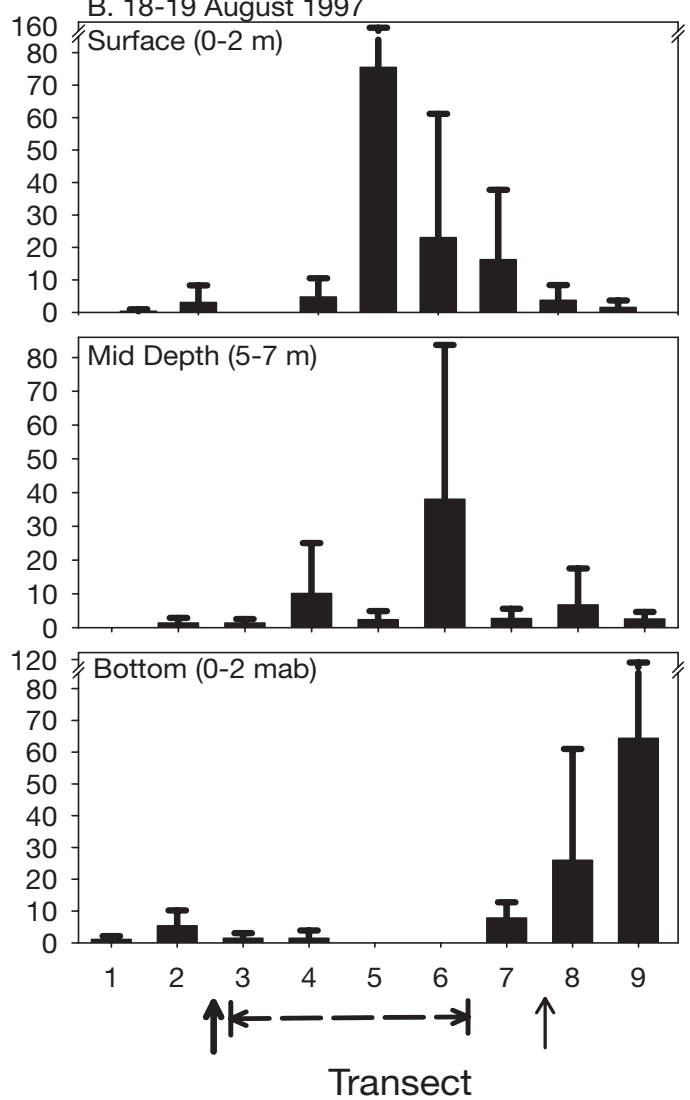

Fig. 6. Pachygrapsus crassipes. Temporal and vertical distribution of Stage I zoeae sampled at San Diego Bay Entrance transect on 4-5 August and 18-19 August 1997. No error bars are presented in (A) since only 1 station was sampled on this date. Further details as in Fig. 5

The relative proportion of Stage I Pachygrapsus crassipes zoeae sampled in the bottom layer at the CBB site during 21 to 22 July, when the sediment-water interface was not sampled (Fig. 5A), was significantly lower $(16.3 \%)$ than the proportion of Stage I zoeae sampled in the bottom layer at the same site on 1 to 2 September $(51.6 \%)$, when the sediment-water interface was sampled (Fig. 5B). The difference in the relative proportion of zoeae found on the bottom between sampling periods is attributable to a larger concentration of larvae collected in the bottom layer during flood-tide conditions, suggesting that a significant proportion of the larvae exploit the sediment-water interface during flood tide (Fig. 5). There was no significant difference in the proportion of $P$. crassipes larvae sampled in the bottom layer during July and September ebb-tide sampling periods (Table 4). Stage I $P$. crassipes zoeae were also concentrated in bottomlayer samples collected at the SDBE site during flood tide conditions of the August sampling periods where the sediment-water interface was sampled $(75.7 \%$, 4 to 5 August; $83.2 \%, 18$ to 19 August) (Fig. 6). P. cras- sipes larval abundance estimates from the July sampling period were not used in subsequent statistical analyses of vertical distribution patterns since bottom samples underestimated larval concentrations during flood-tide conditions.

\section{Lophopanopeus spp.}

The concentration of Lophopanopeus spp. zoeae sampled at the CBB site varied significantly with tidal and diel phase, but neither sampling depth nor the interaction terms were significant (Table 2). Lophopanopeus spp. zoeae were significantly more abundant, across all sampling depths, during ebbing tides (Table 2). This distribution corresponds to maximum horizontal transport from the inner region of SDB, where the majority of Lophopanopeus spp. zoeae are concentrated, towards the CBB sampling site during ebb tide. Since only nocturnal ebb tides were sampled, this probably explains why diel phase had a significant effect on larval abundance at the CBB site. 

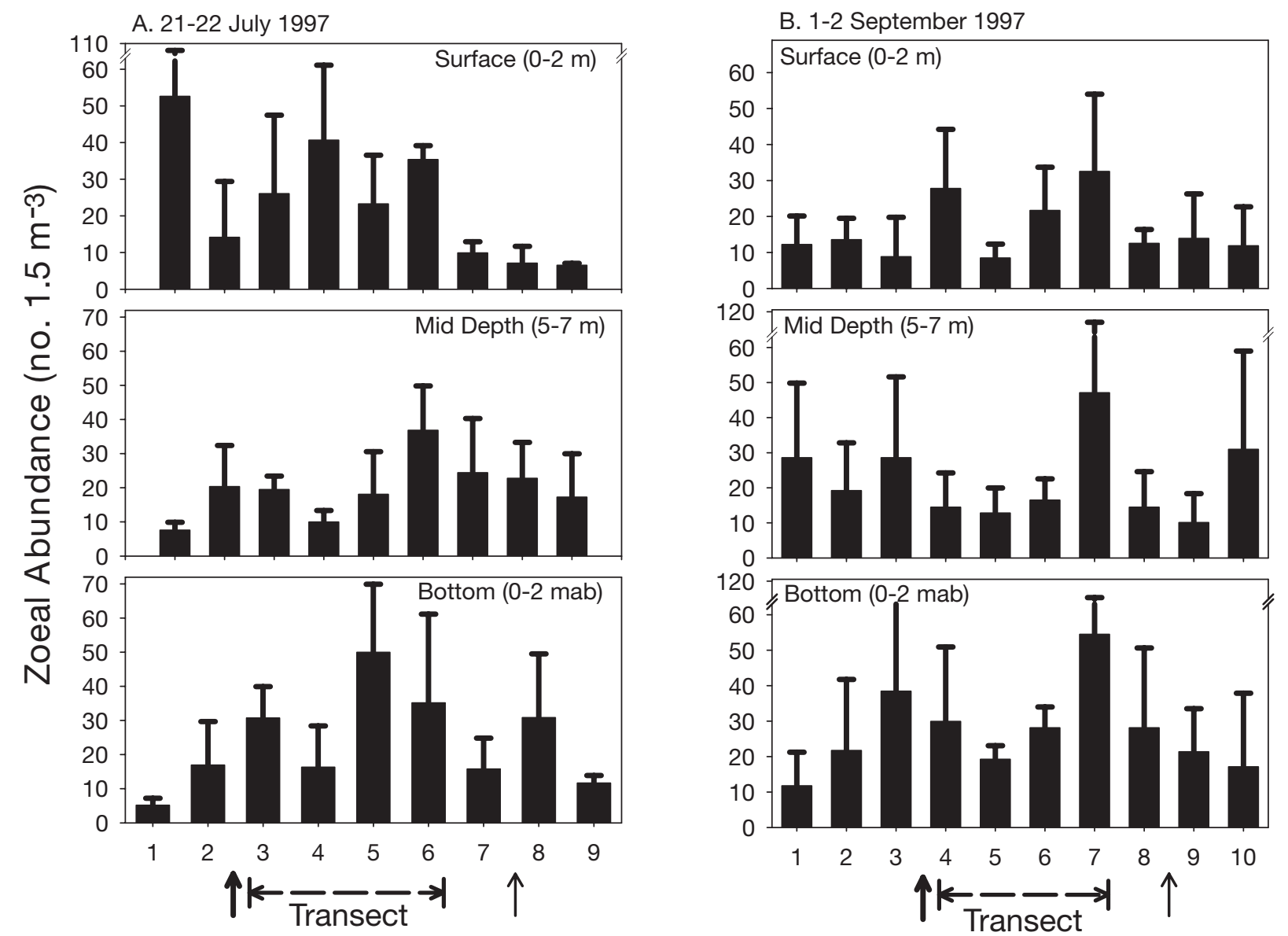

Fig. 7. Lophopanopeus spp. Temporal and vertical distribution of zoeae sampled at Coronado Bay Bridge transect on 21-22 July and 1-2 September 1997. Further details as in Fig. 5

Table 4. Pachygrapsus crassipes and Lophopanopeus spp. One-way ANOVA comparing percent zoeal abundance estimates sampled in the bottom layer for Stage I P. crassipes zoeae and combined Stage I and PostStage I Lophopanopeus spp. zoeae at the Coronado Bay Bridge transect. Sediment-water interface was not sampled during 21-22 July 1997 sampling period (only 0.5 to $2 \mathrm{~m}$ above bottom, mab), while samples collected on 1-2 September 1997 included sediment-water interface (0 to $2 \mathrm{~m}$ above bottom)

\begin{tabular}{|c|c|c|c|c|c|c|}
\hline $\begin{array}{l}\text { Tidal } \\
\text { phase }\end{array}$ & $\begin{array}{l}\text { Sampling } \\
\text { date }\end{array}$ & $\begin{array}{l}\text { Sampling } \\
\text { depth }\end{array}$ & $\begin{array}{c}\text { \% larval } \\
\text { abundance }\end{array}$ & $\mathrm{n}$ & $F$-ratio & $\mathrm{p}$-value \\
\hline \multicolumn{7}{|c|}{ P. crassipes } \\
\hline Flood & $\begin{array}{l}21-22 \mathrm{Jul} \\
1-2 \mathrm{Sep}\end{array}$ & $\begin{array}{l}0.5-2 \mathrm{mab} \\
0.5-2 \mathrm{mab}\end{array}$ & $\begin{array}{l}22.0 \\
75.5\end{array}$ & 31 & 17.096 & $<0.001$ \\
\hline Ebb & $\begin{array}{l}\text { 21-22 Jul } \\
1-2 \text { Sep }\end{array}$ & $\begin{array}{l}0-2 \mathrm{mab} \\
0-2 \mathrm{mab}\end{array}$ & $\begin{array}{l}13.9 \\
20.2\end{array}$ & 22 & 0.926 & 0.346 \\
\hline \multicolumn{7}{|c|}{ Lophopanopeus spp. } \\
\hline Flood & $\begin{array}{l}21-22 \mathrm{Jul} \\
1-2 \mathrm{Sep}\end{array}$ & $\begin{array}{l}0.5-2 \mathrm{mab} \\
0.5-2 \mathrm{mab}\end{array}$ & $\begin{array}{l}30.5 \\
40.4\end{array}$ & 31 & 0.012 & 0.915 \\
\hline Ebb & $\begin{array}{l}21-22 \mathrm{Jul} \\
1-2 \mathrm{Sep}\end{array}$ & $\begin{array}{l}0-2 \text { mab } \\
0-2 \text { mab }\end{array}$ & $\begin{array}{l}38.7 \\
42.1\end{array}$ & 22 & 0.241 & 0.628 \\
\hline
\end{tabular}

Lophopanopeus spp. zoeal concentrations never differed between sampled depths, regardless of tidal or diel phase (Table 3), indicating no detectable vertical migratory behavior. Lophopanopeus spp. zoeae did not appear to settle on the bottom during any phase of the tidal cycle sampled (Fig. 7). Unlike Stage I Pachygrapsus crassipes zoeae, there was no difference in the proportion of Lophopanopeus spp. zoeae sampled in the bottom layer, regardless of whether the sedimentwater interface was sampled (Table 4).

\section{Horizontal distribution of larvae}

\section{Pachygrapsus crassipes}

The distribution of Stage I Pachygrapsus crassipes larvae was heterogeneous 


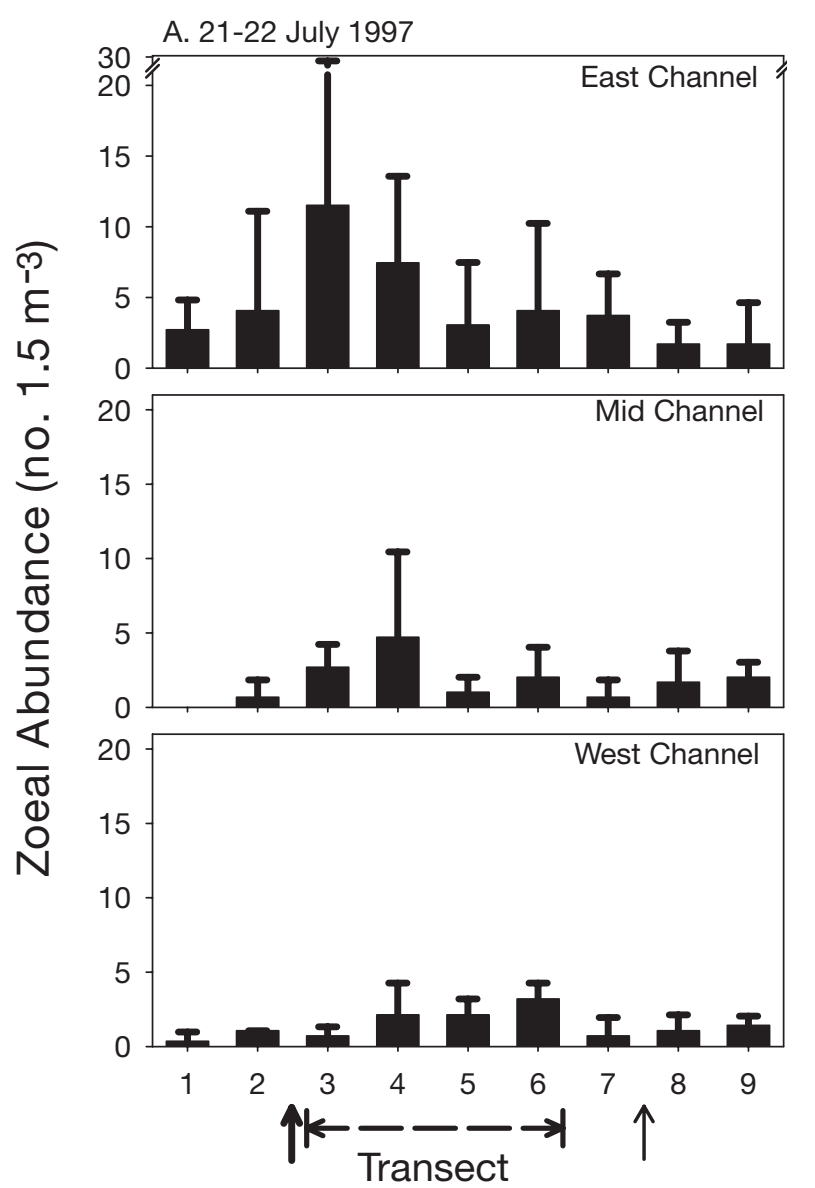

B. 1-2 September 1997

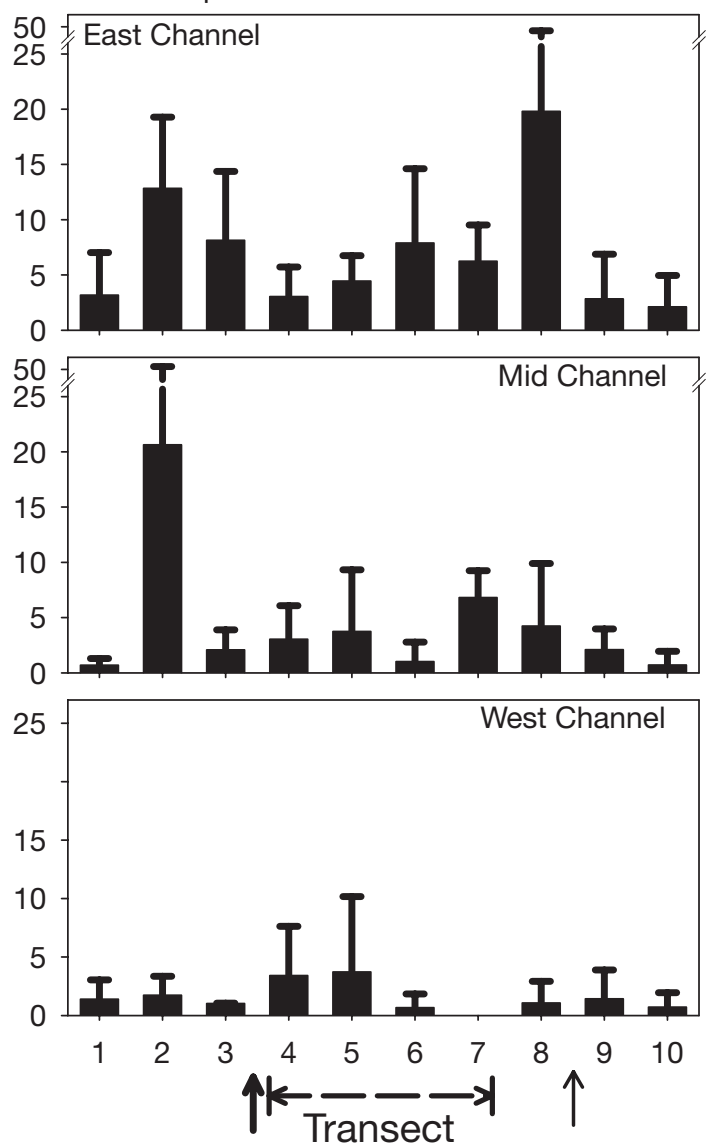

Fig. 8. Pachygrapsus crassipes. Temporal and horizontal distribution of Stage I zoeae sampled at Coronado Bay Bridge transect on 21-22 July and 1-2 September 1997. Mean zoeal abundance was calculated by averaging station-specific larval abundance estimates from surface, mid-depth, and bottom layers for each transect, respectively. Further details as in Fig. 5

across sampling stations of the CBB transect (Table 5). Larvae were usually concentrated in the eastern station of the CBB transect (Fig. 8). During ebb tide, larval densities in the eastern station were higher than in the western station (Fig. 8). Larval density estimates for the mid-channel station did not differ from either eastern or western station densities (Fig. 8). During flood tide, Stage I $P$. crassipes larval densities were highest in the eastern station compared to mid-channel or western station densities (Fig. 8). Larval densities were not significantly different between the mid-channel and western stations (Table 5).

At the SDBE site (B, Fig. 1), the average concentration of larvae collected from the eastern station was greater than either the western or mid-channel stations during ebb tide (Fig. 9B); however, none of the station densities differed significantly (Table 5). The distribution of Pachygrapsus crassipes larvae was heterogeneous during flood tide (Fig. 9B). The western station had a significantly higher density of Stage I zoeae than the mid-channel station, but it did not differ from the eastern station (Table 5).

\section{Lophopanopeus spp.}

Lophopanopeus spp. zoeae were heterogeneously distributed across the CBB transect (Table 5). Larvae were more concentrated in the eastern and mid-channel stations of the CBB transect (Fig. 10). Similar distribution patterns were observed for both Stage I and Post-Stage I Lophopanopeus spp. zoeae sampled during July and September; therefore statistical results for analyses on densities of combined larval stages of development are presented in Table 5. Lophopanopeus spp. larval densities were lower at the western station during ebb tides than at either the eastern or mid-channel stations. Mean larval densities sampled during flood tide remained lower at the western station than at either the eastern station or the mid-channel stations (Fig. 10). 


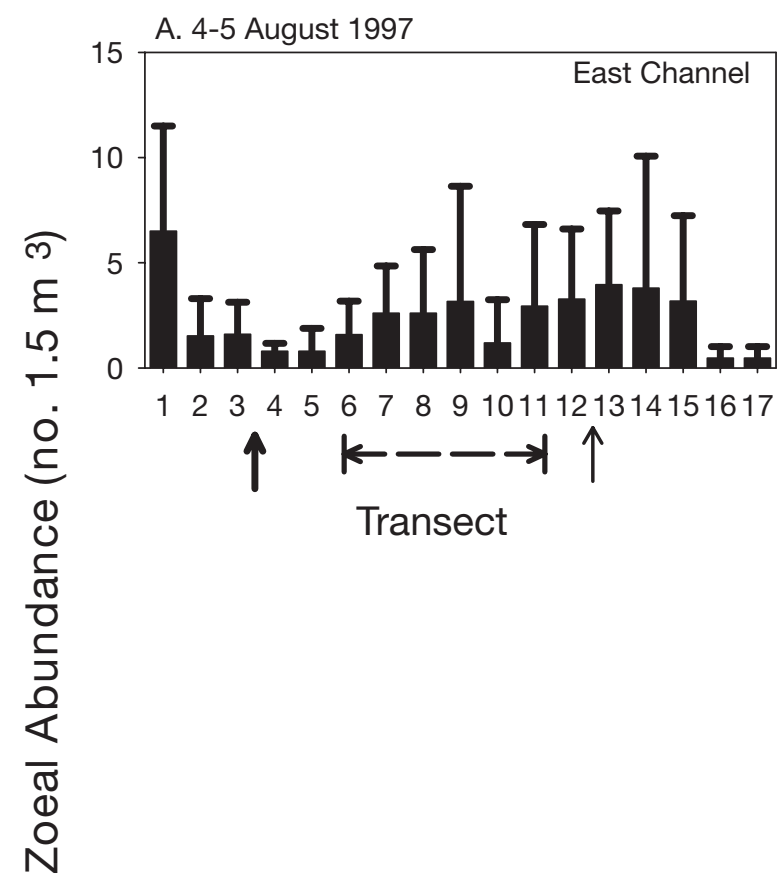

B. 18-19 August 1997
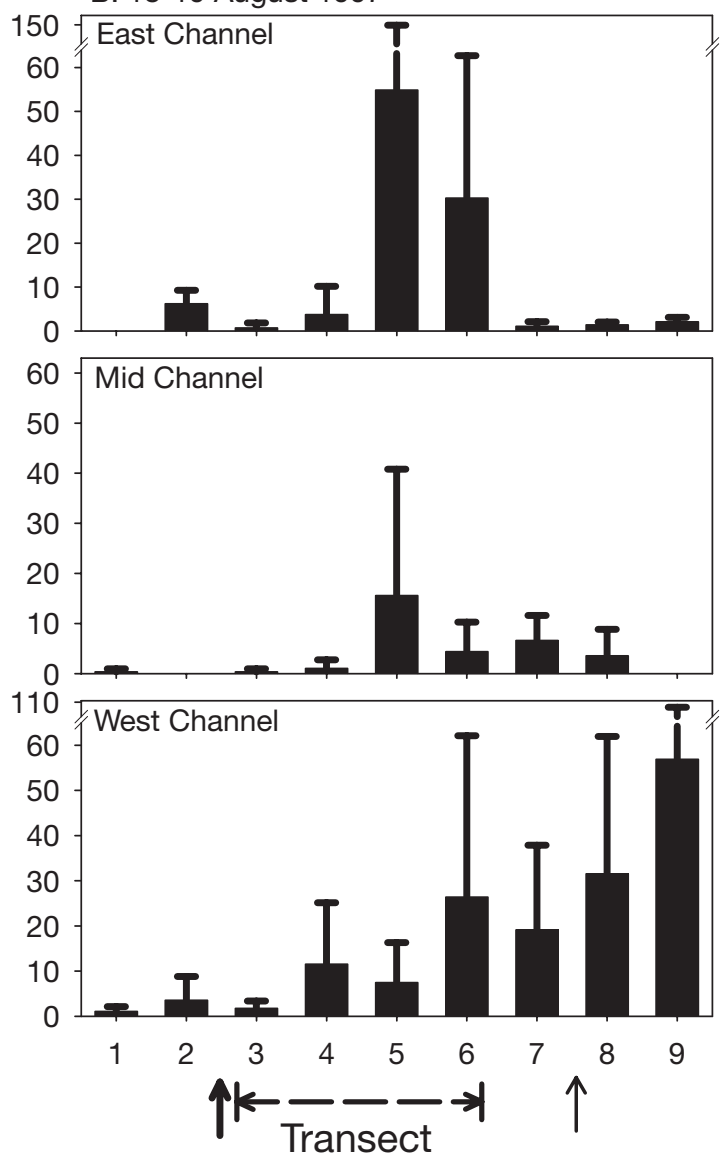

Fig. 9. Pachygrapsus crassipes. Temporal and horizontal distribution of Stage I zoeae sampled at San Diego Bay Entrance transect on 4-5 August (only eastern station sampled) and 18-19 August 1997. Further details as in Figs 5 \& 8

Table 5. Pachygrapsus crassipes and Lophopanopeus spp. One-way ANOVA comparing larval abundance estimates (mean \pm SD) for eastern (E), mid-channel (M), and western (W) stations sampled during ebb and flood tides at Coronado Bay Bridge transect (CBB: 21-22 July 1997, 1-2 September 1997) and San Diego Bay Entrance transect (SDBE: 18-19 August 1997). Larval abundance data for Stage I P. crassipes zoeae and Stage I and Post-Stage I Lophopanopeus spp. zoeae were analyzed for ebb, flood and pooled ebb and flood tides. Results from pooled Lophopanopeus spp. larvae are presented, since the same statistically significant effects were revealed in separate analyses of Stage I and Post-Stage I zoea. Statistically significant multiple-comparison results (Bonferroni-corrected Student's $t$-test) are given for each ANOVA which identified a significant effect of tidal phase on larval abundance. Data from 4-5 August 1997 sampling period were combined with the 18-19 August 1997 data analyzed here since only the eastern portion of the channel and a significantly higher concentration of $P$. crassipes larvae were sampled during the former period. ${ }^{*} 0.05>\mathrm{p}>0.01 i^{* *} 0.01>\mathrm{p}>0.001,{ }^{* * *} \mathrm{p}<0.001$

\begin{tabular}{|c|c|c|c|c|c|c|c|c|}
\hline Sampling site & Tidal phase & East & Middle & West & $\mathrm{n}$ & F-ratio & $\mathrm{p}$-value & Student's $t$ \\
\hline \multicolumn{9}{|l|}{ P. crassipes } \\
\hline \multirow[t]{2}{*}{$\mathrm{CBB}$} & Ebb & $5.9(0.8)$ & $3.1(0.7)$ & $2.0(0.1)$ & 69 & 4.905 & 0.011 & $\mathrm{E}=\mathrm{M}, \mathrm{E}>\mathrm{W}^{* *}, \mathrm{M}=\mathrm{W}$ \\
\hline & Flood & $5.5(3.8)$ & $3.1(2.9)$ & $1.1(0.2)$ & 96 & 7.092 & $<0.001$ & $\mathrm{E}>\mathrm{M}^{*}, \mathrm{E}>\mathrm{W}^{* *}, \mathrm{M}=\mathrm{W}$ \\
\hline \multirow[t]{2}{*}{ SDBE } & Ebb & $12.4(14.2)$ & $6.9(6.2)$ & $16.1(8.4)$ & 42 & 1.866 & 0.167 & - \\
\hline & Flood & $2.2(0.2)$ & $1.1(1.7)$ & $18.9(24.7)$ & 30 & 3.380 & 0.047 & $\mathrm{E}=\mathrm{M}, \mathrm{E}=\mathrm{W}, \mathrm{M}<\mathrm{W}^{*}$ \\
\hline \multicolumn{9}{|c|}{ Lophopanopeus spp. } \\
\hline \multirow[t]{2}{*}{$\mathrm{CBB}$} & Ebb & $30.2(3.5)$ & $34.8(0.4)$ & $16.9(2.0)$ & 69 & 5.619 & 0.006 & $E=M, E>W^{* *}, M>W^{* *}$ \\
\hline & Flood & $20.4(6.8)$ & $19.9(1.2)$ & $14.6(4.7)$ & 96 & 4.096 & 0.020 & $\mathrm{E}=\mathrm{M}, \mathrm{E}=\mathrm{W}, \mathrm{M}>\mathrm{W}^{*}$ \\
\hline
\end{tabular}



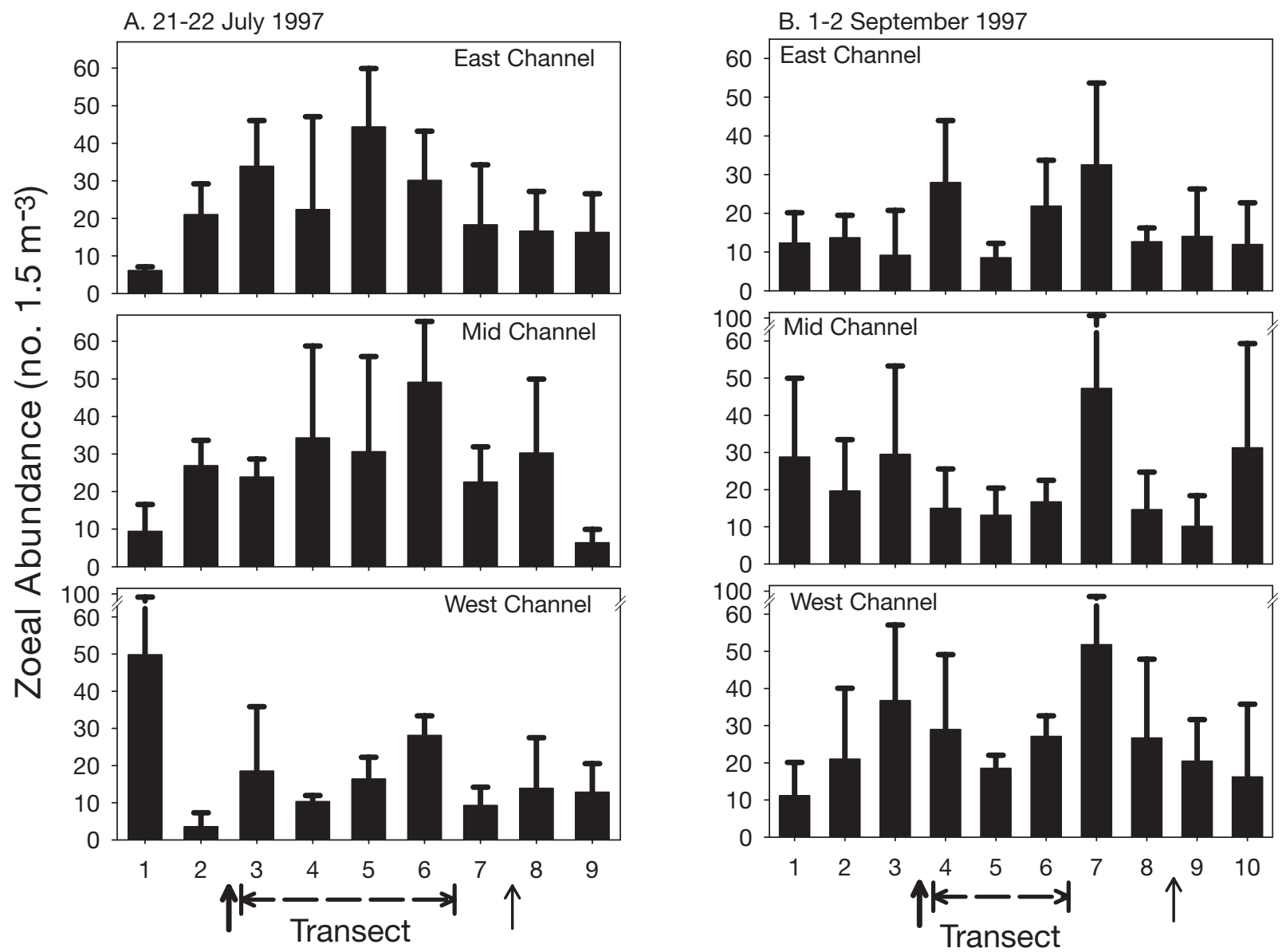

Fig. 10. Lophopanopeus spp. Temporal and horizontal distribution of Stage I zoeae sampled at Coronado Bay Bridge transect on 21-22 July and 1-2 September 1997. Further details as in Figs 5 to 8

\section{DISCUSSION}

\section{Vertical distribution of larvae}

\section{Pachygrapsus crassipes}

A large body of laboratory and field evidence suggests that the export or retention of brachyuran larvae spawned in estuaries is not a passive phenomenon. Many brachyuran larvae facilitate their export from or retention within embayments with specific adaptations, such as tidally timed vertical migratory behavior (e.g., Epifanio 1988, McConaugha 1988). Stage I Pachygrapsus crassipes zoeae sampled in this study appear to minimize their residence time within SDB by aggregating in surface layers during nocturnal ebbing tides and at the sediment-water interface during flood tide (i.e., selective tidal stream transport). Stage I P. crassipes zoeae were observed to burrow to a depth of $2 \mathrm{~cm}$ when hatched in the laboratory and raised in still water in aquariums with coarse sand bottoms (DiBacco 1999).
This burrowing behavior has never been examined in situ for brachyuran larvae because of sampling limitations. If $P$. crassipes larvae, or other meroplankton, can selectively settle on or burrow into sediments during specific phases of the tide, this would allow them to effectively escape transport by unfavorable tides and currents and would enhance the efficiency of selective tidal stream transport. In an LIE such as SDB, exploiting the bottom layer to avoid retention by flooding tides and currents should be particularly advantageous for species like $P$. crassipes that exploit ebbing tides to exit embayments. TRIM2D simulations suggested that larvae settling on the bottom during the flood-tide phase would be considerably more efficient at exiting SDB than larvae which exploited reduced flows in the bottom boundary layer during flood tide (Fig. 4).

Selective tidal stream transport was highly effective in exporting simulated larvae from SDB (Figs 2A-D \& 3A). Field observations revealed a limited proportion of Post-Stage I Pachygrapsus crassipes zoeae $(<1 \%)$ at both the CBB and SDBE sampling sites. Vertical migra- 
tion exhibited by Stage I $P$. crassipes zoeae sampled in the field allowed them to exit SDB before molting to subsequent larval stages of development. P. crassipes zoeae reared under laboratory conditions at ambient bay temperatures $\left(18\right.$ to $20^{\circ} \mathrm{C}$ ) required between 68 and $108 \mathrm{~d}$ to develop through all 6 zoeal stages of development, and averaged about 10 to $15 \mathrm{~d}$ per larval stage of development (DiBacco 2001). Lophopanopeus spp. zoeae exhibited no apparent vertical migratory behavior and were retained within SDB through all larval stages of development.

Numerous studies have examined the vertical distribution of brachyuran larvae relative to tidal and diel cycles and provided evidence for selective tidal stream transport based on reductions in estuarine tidal current velocities within the benthic boundary layer (most recently, Lochmann et al. 1995, Queiroga et al. 1997, Rodriguez et al. 1997, Garrison 1999). Tidally timed rhythmic migrations have been observed for other grapsid crabs which export newly hatched larvae to coastal waters (e.g., Sesarma cinereum, S. reticulatum: Christy \& Stancyk 1982; S. catenata: Lago 1993) and for other panopeid species which retain planktonic stages of larval development within estuaries until recruitment to adult populations (e.g., Rhithropanopeus harrisii: Cronin \& Forward 1979, 1982, Lambert \& Epifanio 1982). However, none of these studies have sampled the sediment-water interface to establish the presence or absence of larvae on the bottom (Lochmann et al. 1995). The present study is the first to provide evidence that a brachyuran species, Pachygrapsus crassipes, may exploit the sediment-water interface to enhance selective tidal stream transport during larval development. Knowledge of the difference in mean velocities experienced by larvae which settle on the bottom (approaching $0 \mathrm{~cm} \mathrm{~s}^{-1}$ ) relative to those distributed through a layer above the bottom is needed to evaluate the relative efficiency of vertical migratory behavior. In LIEs such as SDB, P. crassipes may reduce its residence time within the bay by reducing transport back into the bay during flood tides.

\section{Lophopanopeus spp.}

Marine invertebrate larvae with limited vertical migratory behavior that are passively distributed by currents will experience limited net transport in an LIE such as SDB because of negligible freshwater inflow and weak seaward residual currents. Limited net transport of passive simulated larvae and field-sampled Lophopanopeus spp. zoeae was apparent in SDB. Lophopanopeus spp. zoeae were uniformly distributed throughout depth strata sampled in this study without any indication of tidally timed spawning by ovigerous females or vertical migratory behavior by planktonic zoeae. The persistence of all panopeid larval stages of development at the CBB sampling site (inner SDB), negligible densities at the SDBE site (outer SDB), and model simulation results all suggest that Lophopanopeus spp. zoeae are retained in SDB throughout larval development despite the lack of vertical migratory behavior. Residence time estimates for SDB seawater are on the order of $50 \mathrm{~d}$ in the vicinity of the CBB site and even higher in the innermost regions of the bay (Chadwick \& Largier 1999). Lophopanopeus spp. zoeae typically have 4 zoeal stages of development, which are completed in about $5 \mathrm{wk}$ under laboratory conditions (Hart 1935, Knudsen 1958, 1959). This is considerably shorter than the predicted residence times for inner SDB constituents that disperse passively (Fig. 3B). Garrison (1999) reported that tidally timed migration patterns of panopeid larvae in the York River, a partially mixed estuary in Chesapeake Bay, promoted very slow downstream dispersal, yet Post-Stage I panopeid zoeae were not reported in samples.

Zoeae of another panopeid, Rhithropanopeus harrisii, have been shown to employ tidally timed, rhythmic migration into surface layers during flood tide and into bottom layers during ebb tide to maintain their position within estuaries (Sandifer 1975, Lambert \& Epifanio 1982). This is the reverse of the migration behavior of Stage I Pachygrapsus crassipes' zoeae described in this study, which facilitated transport from SDB. Cronin \& Forward (1982, 1983) observed that $R$. harrisii might aggregate around depths of no net flow during the ebb-tide phase to avoid transport out of estuaries. The lack of non-tidal residual currents in SDB and the lack of net downstream transport and flushing may preclude the need for rhythmic vertical migration by Lophopanopeus spp. zoeae, and perhaps other passive meroplanktonic or holoplanktonic species, to retain larvae within the bay.

\section{Horizontal distribution of larvae}

The horizontal distribution of newly hatched zoeae may be influenced by the distribution of adult populations. In the case of Pachygrapsus crassipes, newly hatched larvae were concentrated in the eastern station of the CBB transect during flood and ebb tides. The eastern side of this region of SDB has both natural (e.g., Sweetwater Marsh) and artificial (e.g., piers and jetties) habitats occupied by adult $P$. crassipes. The opposite shore is sandy (Silver Strand) or has been replaced by concrete docks and boardwalks (North Island) that provide little or no habitat for P. crassipes. As a result, most Stage I $P$. crassipes larvae hatched near the CBB sampling site originate from the eastern side of the bay. 
Once larvae are released into the water column, physical features can concentrate or disperse them. For example, an intensified ebb-tide current that develops on the eastern side of the channel extending from inside the Coronado Bay Bridge past the CBB site has been documented by Chadwick \& Largier (1999). This tidal jet would entrain newly released zoeae and keep them concentrated in the eastern region of the channel, within a few hundred meters from shore. Model simulations predicted that larvae spawned from the eastern side of SDB would remain most concentrated on the eastern side of the channel (Fig. 2). Maximum velocity estimates of this ebb-jet have been reported to be about $50 \mathrm{~cm} \mathrm{~s}^{-1}$ in the eastern side of the channel and $25 \mathrm{~cm} \mathrm{~s}^{-1}$ in the western side of the channel (Chadwick \& Largier 1999). Flood-tide velocities were symmetrical across the channel, with maximum velocities in the middle of the channel (40 to $45 \mathrm{~cm} \mathrm{~s}^{-1}$ ) and decreasing velocities closer to shore (20 to $25 \mathrm{~cm} \mathrm{~s}^{-1}$ $100 \mathrm{~m}$ from either shore) (Chadwick \& Largier 1999). The horizontal distribution of Stage I P. crassipes zoeae sampled at the entrance of SDB and tidal velocity estimates reported were more spatially uniform across stations than at the CBB site (Chadwick \& Largier 1999).

Differences in the horizontal distribution of Stage I Pachygrapsus crassipes and panopeid larvae relative to tidal currents at each site will affect larval exchange between regions of SDB and between SDB and nearshore coastal waters. In the case of panopeid larvae, the vertical distribution, which is uniform, may be less important to net transport than the observed horizontal distribution relative to tidal currents at the CBB site. In contrast to the situation for $P$. crassipes, the eastern and western sides of the inner SDB channel provide some suitable habitat for adult panopeid populations. The more extensive development of military, commercial and recreational piers, which support intertidal mussel communities inhabited by Lophopanopeus spp., near the eastern station than the western station may explain the larger concentration of panopeid larvae sampled in the western station of the CBB sampling transect (Fig. 10).

\section{Significance of bay-ocean exchange}

The vast majority of studies considering temporal and spatial distributions of brachyuran larvae have been conducted in partially mixed estuaries where significant freshwater inflow results in non-tidal residual flows and net downstream transport of passive and uniformly distributed constituents. The present study considered the vertical migratory behavior of crab larvae in SDB, an LIE which experiences negligible or no net downstream flow due to limited freshwater input. Tidal stream transport appears necessary for Pachygrapsus crassipes larvae to exit SDB, based on the retention of Lophopanopeus spp. larvae (which lacked vertical migration behavior) within SDB through all planktonic stages of development. The efficiency of rhythmic vertical migration in promoting export appears to be enhanced by $P$. crassipes' ability to exploit velocity gradients that approach zero near the sediment-water interface during flood tides. Swimming behavior-mediated retentive mechanisms were not necessary for retention of Lophopanopeus spp. larvae within SDB.

A trade-off between nutrition, predation, and physiological stress have been offered as an explanation why certain larvae may be preferentially exported from estuaries while others are retained throughout their development (reviewed by Morgan \& Christy 1995, 1997). In a separate study, Pachygrapsus crassipes larvae cultured in coastal seawater experienced higher survivorship during zoeal development and yielded a larger percentage of viable megalopae than larvae reared in SDB seawater (DiBacco 2001). Thus, $P$. crassipes larvae leaving SDB for open coastal waters should experience an increased probability of surviving to the megalopal stage of development, the stage that recruits to sedentary benthic populations. Vertical migratory behavior, which can facilitate the export or retention of select crab species during planktonic larval development, can reduce predation pressure and physiological stress associated with coastal habitats, while retention within an embayment throughout planktonic larval development can reduce dispersal from the adult habitat and enhance recruitment.

Acknowledgements. We thank Josh Bernd, Bart Chadwick, Jeffrey Crooks, Jana Davis, Andrew Juhl, Amy Larson, Cleridy Lennert, Lisa Levin, Christopher Martin, Anthony Rathburn, Matthias Saladin, Todd Switzer, Emma Takahashi and Drew Talley for field assistance. We thank Lisa Levin and 3 anonymous reviewers for contributions to the present manuscript. This research was supported by the Office of Naval Research (N00014-96-1-0025). C.D.B. was also supported by the Natural Sciences and Engineering Research Council of Canada, a Mildred E. Mathias Graduate Student Research Grant, and a University of California Toxic Substance Research and Teaching Program Graduate Student Fellowship.

\section{LITERATURE CITED}

Bousfield EL (1955) Ecological control of the occurrence of barnacles in the Miramichi Estuary. Bull Nat Mus Can 137:1-69

Carriker MR (1951) Ecological observations on the distribution of oyster larvae in New Jersey estuaries. Ecol Monogr 21:19-38

Chadwick DB, Largier JL (1999) Tidal exchange at the bayocean boundary. J Geophys Res 104:29901-29924

Cheng RT, Casulli V, Gartner JW (1993) Tidal, residual, inter- 
tidal mudflat (TRIM) model and its applications to San Francisco Bay, California. Estuar Coast Shelf Sci 36: 265-280

Chia FS, Buckland-Nicks J, Young CM (1984) Locomotion of marine invertebrate larvae: a review. Can J Zool 62: 1205-1222

Christy JH (1982) Adaptive significance of semilunar cycles of larval release in fiddler crabs (genus Uca): test of a hypothesis. Biol Bull 163:251-263

Christy JH, Stancyk SE (1982) Timing of larval production and flux of invertebrate larvae in a well-mixed estuary. In: Kennedy VS (ed) Estuarine comparisons. Academic Press, New York, p 489-503

Conway JH, Gilb RA (1989) A final report on the San Diego Bay Drainage Sampling Program. San Diego Regional Water Quality Control Board and the State Water Resources Control Board, Long Beach, CA

Cronin TW (1982) Estuarine retention of larvae of the crab Rhithropanopeus harrisii. Estuar Coast Shelf Sci 15: 207-220

Cronin TW, Forward RB Jr (1979) Tidal vertical migration: an endogenous rhythm in estuarine crab larvae. Science 204:1020-1022

Cronin TW, Forward RB Jr (1982) Tidally-timed behavior: effects on larval distribution in estuaries. In: Kennedy VS (ed) Estuarine comparisons. Academic Press, New York, p 505-520

Cronin TW, Forward RB Jr (1983) Vertical migration rhythms of newly hatched larvae of the estuarine crab, Rhithropanopeus harrisii. Biol Bull 165:139-153

DiBacco C (1999) Bay-ocean exchange of crab larvae: the roles of larval behavior, origins, distribution and physical processes. PhD dissertation, University of California, San Diego

DiBacco C (2001) The influence of bay versus coastal habitats on development and survival of striped shore crab larvae (Pachygrapsus crassipes Randall 1840). Bull S Calif Acad Sci 99:161-170

Dyer KR (1997) Estuaries: a physical introduction, 2nd edn. John Wiley \& Sons, Chichester

Epifanio CE (1988) Transport of invertebrate larvae between estuaries and the continental shelf. Am Fish Soc Symp 3: $104-114$

Garrison LP (1999) Vertical migration behavior and larval transport in brachyuran crabs. Mar Ecol Prog Ser 176: 103-113

Hart JL (1935) The larval development of British Columbia Brachyura. Can J Res 12:411-432

Ingle R (1992) Larval stages of northeastern Atlantic crabs. Chapman \& Hall, London

Knudsen JW (1958) Life cycle studies of the brachyura of western North America. I. General culture methods and the life cycle of Lophopanopeus leucomanus leucomanus (Lockington). Bull S Calif Acad Sci 57:51-59

Knudsen JW (1959) Life cycle studies of the brachyura of western North America. II. The life cycle of Lophopanopeus bellus diegensis Rathbun. Bull S Calif Acad Sci 58:57-58

Lago RP (1993) Tidal exchange of larvae of Sesarma catenata (Decapoda, Brachyura) in the Swartkops estuary, South Africa. S Afr J Zool 28:182-191

Lambert R, Epifanio CE (1982) A comparison of dispersal strategies in two genera of brachyuran crab in a secondary estuary. Estuaries 5:182-188

Largier JL, Hearn CJ, Chadwick DB (1996) Density structures in 'low inflow estuaries'. In: Bowman MJ, Mooers CNK (eds) Coastal and estuarine studies, buoyancy effects on coastal and estuarine dynamics. American Geophysical Union, Washington, DC, p 227-241

Largier JL, Hollibaugh JT, Smith SV (1997) Seasonally hypersaline estuaries in Mediterranean climate regions. Estuar Coast Shelf Sci 45:789-797

Levin LA, Bridges T (1995) Pattern and diversity in reproduction and development. In: McEdward L (ed) Ecology of marine invertebrate larvae, CRC Press, Boca Raton, FL, p 1-48

Lochmann SE, Darnell RM, McEachran JD (1995) Temporal and vertical distribution of crab larvae in a tidal pass. Estuaries 18:255-263

McConaugha JR (1988) Export and reinvasion of larvae as regulators of estuarine decapod populations. Am Fish Soc Symp 3:90-103

McConaugha JR (1992) Decapod larvae: dispersal, mortality, and ecology. A working hypothesis. Am Zool 32:512-523

Morgan SG, Christy JH (1995) Adaptive significance of the timing of larval release by crabs. Am Nat 145:457-479

Morgan SG, Christy JH (1997) Planktivorous fishes as selective agents for reproductive synchrony. J Exp Mar Biol Ecol 209:89-101

Morris RH, Abbott DP, Haderlie EC (1980) Intertidal invertebrates of California. Stanford University Press, Stanford, $\mathrm{CA}$

Paula J (1989) Rhythms of larval release of decapod crustaceans in the Mira Estuary, Portugal. Mar Biol 100:309-312

Peeling T (1974) A proximate biological survey of San Diego Bay, California. Naval Undersea Research and Development Center, San Diego, CA, Tech Rep No. TP389

Pritchard DW (1952) Estuarine hydrography. In: Advances in geophysics. Academic Press, New York, p 243-280

Prytherch HF (1928) Investigation of the physical conditions controlling spawning of oysters and the occurrence, distribution and setting of oyster larvae in Milford Harbor, Connecticut. Bull Bur Fish Wash 44:429-503

Queiroga HJ, Costlow D, Morieira MH (1994) Larval abundance patterns of Carcinus maenas (Decapoda, Brachyura) in Canal de Mira (Ria de Aveiro, Portugal). Mar Ecol Prog Ser 111:63-72

Queiroga HJ, Costlow JD, Moreira MH (1997) Vertical migration of the crab Carcinus maenus first zoeae in an estuary: implications for tidal stream transport. Mar Ecol Prog Ser 149:121-132

Rice AL (1980) Crab zoeal morphology and its bearing on the classification of the Brachyura. Trans Zool Soc Lond 35 $271-424$

Ricketts EF, Calvin J, Hedgpeth JW (1985) Between Pacific tides. Stanford University Press, Stanford, CA

Rodriguez A, Drake P, Arias AM (1997) Reproductive periods and larval abundance patterns of the crabs Panopeus africanus and Uca tangeri in a shallow inlet (SW Spain). Mar Ecol Prog Ser 149:133-142

Sandifer PA (1975) The role of pelagic larvae in recruitment to populations of adult decapod crustaceans in the York River estuary and adjacent lower Chesapeake Bay, Virginia. Estuar Coast Mar Sci 3:269-279

Schlotterbeck RE (1976) The larval development of the lined shore crab, Pachygrapsus crassipes Randall, 1840 (Decapoda, Brachyura, Grapsidae) reared in the laboratory. Crustaceana 30:184-200

Sokal RR, Rohlf FJ (1994) Biometry. The principles and practice of statistics in biological research, 3rd edn. WH Freeman \& Co, New York

Wang PF, Cheng RT, Richter K, Sutton DW, Gross EW, Gartner JW (1998) Modeling tidal hydrodynamics of San Diego Bay, California. J Am Water Res Assoc 34:1123-1140 